\title{
Dividend Announcement and Firm Value: A Test of Semi Strong Form of Efficiency at the Nairobi Stock Exchange
}

\author{
Tobias Olweny \\ Lecturer, Department of Commerce and Economic Studies, Jkuat, Kenya \\ E-mail: toolweny@yahoo.com
}

Received: April 6, $2011 \quad$ Accepted: July 12, $2011 \quad$ Published: January 1, 2012

doi:10.5539/ass.v8n1p161 URL: http://dx.doi.org/10.5539/ass.v8n1p161

\begin{abstract}
The issue surrounding policy makers is whether dividend announcements have information content. This study investigated into this concept to determine the extent, to which dividend announcements have information content, its effect on firm value and what this implied on the semi strong efficiency of the Nairobi Stock Exchange (NSE). A sample of trading delays in each year for the period 1999- 2003 was drawn from firms listed on NSE. The data was purely secondary data of the firms listed on the NSE, stock prices and dividend announcements. The event study methodology was used analyze information content of dividend announcements for the four firms.

The results based on an estimation window of more than hundred trading days per year show that, for the analyzed firms, dividend announcements do indeed convey useful information about the future value of a firm. This empirical investigation came up with the following findings: First Dividend announcements have pertinent information, which is consistent with Modigliani and Miller (1958) information content hypothesis. Second, the information content in dividend announcements significantly affects the firm value as shown by large spikes in the graphs. Third the NSE is not semi strong from efficiency and therefore market participants can make abnormal profits by trading on public information, such as dividend announcements.
\end{abstract}

Keywords: Market efficiency, Dividend, Firm value

\section{Introduction}

The study is based on the efficiency of the stock market, which Fama (1965, 1970 and 1991) defines at three levels; weak, semi-strong and strong forms. It concentrates on the semi - strong form efficiency and specifically the effects of dividend announcements on firma value. In the study, the stock price is used as a proxy for firm value. The Kenya's stock market, Nairobi Stock Exchange (NSE) plays a very important role in hastening of capital for development. It enables a company to access a wide variety of investors and thus diversify its risk and place it to public scrutiny. For the market to operate effectively the availability of information on the market is pertinent as it helps to determine the level of efficiency and sophistication attained by the market. This study concentrated mainly on the effect of public information on firm value. Public information effect on firm value is always at the entire of media and business attention and is therefore of considerable importance not only in developed markets but also in emerging markets. The announcement effects of corporate actions on firm value dates as far back as the first published study by Dolley (1933); who examined the price effects of stock splits.

The theory underpinning of dividend announcement on firm revolves around two schools of thought, which have divergent views. First is theoretical literature developed by Lintner (1956) who postulated that current dividends convey a considerable amount of information about firm value. He noted that at least for large firms, dividends tend to be inflexible in the downward direction; firms tend to make positive dividends announcement to support the higher rate of payment. He further observed that dividends should be decreased only when management is assured that cash flows will be insufficient to support the present dividend payout rate. The second school is based on literature developed in a study by Watts (1973) who found that although dividend announcements may contain some information, the absolute size of the future value, which might be conveyed by dividend announcements, is very small. Therefore the information content of dividends is trivial. Although the two strands of literature allude to the hypothesis that dividend announcements contain information the triviality of the information content of the announcements remains a hot issue and has opened up ranging debate on whether or not dividend announcements have some information contents. 


\subsection{Conceptual framework}

The conceptual framework of the effect of dividend announcements (independent variable) on the firm value proxied by stock price) dependent variable) was examined as shown by figure 1 below. Conceptually, the study examined the information contained in the dividend announcements and how that information signals and affects the value of the firm and its implication on the semi strong from efficiency of NSE.

\subsection{Theoretical literature review}

\subsubsection{The information content of dividends hypothesis ( $\mathrm{ICH}$ )}

The ICH is one the most referred to hypotheses in economics literature in so far as the impact of dividend announcement on stock prices is concerned. The hypothesis was developed by Modigliani and Miller (1958). They postulated that under the assumptions of perfect capital markets, rational behavior and zero taxes, the value of the firm does not depend on the firm's announcement of a dividend. Durand (1959) questioned whether this conclusion was consistent with the then existing evidence, which consisted mostly of strong positive cross sectional correlations of price with dividends. However, in their reply to Durand, Modigliani and Miller explained that a firm's market value depends on its expected future value. Thus if the value which is determined by a firms market performance consists of permanent and transitory components and if dividends depend on the former, dividend announcement would serve as a surrogate for expected future value, and such a surrogate relationship might explain the results of the cross sectional studies

This hypothesized relationship was labeled by the two as the information content of dividends. This suggests that the announcement of dividend has no impact on stock prices in the face of the idealistic assumptions put up by the pair. Since its exposition by Modigliani and Miller (1958) the information content hypothesis has been frequently quoted in articles and texts of financial economics as a possible explanation of observed relationship between dividend announcements and stock price.

\subsubsection{Cash flow signaling hypothesis ( CFSH)}

The pioneer of this theory was Kalay (1980, who developed a model on what signals is sent to market when there is an unexpected dividend announcement that lead to a cut in actual dividend. He argued that, managers are reluctant to cut dividends as a necessary condition for dividends to convey information. This hypothesis contends that unexpected dividend announcement that suggest increases in dividends signals the fact that the firm's financial position is favorable and that it has good investment projects in its portfolio, and therefore is able to generate positive cash flows in the long term. This would lead to an increase in the stock prices of the firm.Similarly, investors view an unexpected announcement that leads to a cut in dividends relative to the previous period level as an indictment of the firm as having bleak future. According to Kalay (1980) this negative signal would lead to a fall of the firm's stock price. Consistent with Kalay (1980) hypothesis, Aharony and Swary (1980) found that announcing firms experience substantial abnormal returns at the time of their dividend announcement. According to them the abnormal returns are larger in absolute value for dividend decreases, and this would lead to a market fall of the firm's stock

\subsubsection{The free cash flow hypothesis (FCFH)}

The FCFH was propounded by Jensen who postulated that a firm with substantial free cash flows would encourage managers to have a tendency of over investing by accepting marginal investment projects with negative present values. If managers over invest, an unexpected dividend announcement leading to an increase in dividend would lead to a reduction in the amount of available cash flows and limit over investing. Consequently, the improved projection of the firm to the investors would lead to an increase in the stock price of the firm and therefore, its market value. Conserves, a reduction in dividends would facilitate over investing and as a consequence lead to a fall in stock price

\subsubsection{The coarse dividend signaling Theory (CDST)}

This theory was developed by Warther (1994) who was interested in establishing the impact of a dividend announcement resulting from a cut in the dividend level. In his analysis, he predicted that dividends are more likely to have information when they are decreased than when they are increased. According to him, if a company has been making losses in the past an announcement resulting from a cut in dividend turns market sentiments against the holding of shares of such a firm leading to a fall in the stock price of that firm.

\subsubsection{The tax preference hypothesis ( TPH)}

Other researchers have made efforts to further understand the impact of a dividend announcement on firm value in the face of taxation. Among them , Brennan (1970 and 1973) Litzenberger and Ramaswamy (1979 and 1080) 
showed that it is optimal for a positive dividend announcement to be made if marginal tax rate is greater than Zero and investors after tax expected are of return depends on the dividend yield and systematic risk. This leads to an argument that dividend announcements might have some tax included effect on share prices. According to them, average investors, subject to their personal tax rates, would prefer to have les chase dividend if it is taxable. The size of optimal dividend is inversely related to personal income tax rates (Pye 1972) hence stock prices tend to decline after the announcement of a dividend increase. Subsequent studies by Bhattacharya (1979) developed a theoretical model of dividend signaling that included signaling cost. In his model, signaling costs are a function of the differential tax treatment of dividend versus capital income.

\subsection{Review of empirical studies}

Uddin (2003) conducted a study to establish the effect of divided announcements on shareholders' value using Dhaka stock exchange (DSE) as a case study. This empirical study was based on 137 samples of dividend paying companies listed on the DSE. These are companies that announced dividends between October 2002 and September 2002. He chose this period following immediately after the change of political power in Bangladesh to avoid high market vitality. The choice of companies that were included in the sample depended on the sector to which they belonged and the overall included stocks from all sectors. From each sector, Uddin selected 10 to 20 stocks except in Paper, Jute and the services sectors. The event study methodology was used to calculate the security return, expected return, market adjusted abnormal return and the daily cumulative abnormal return. The research also used the DSE all share price index as the proxy for average market price. The event window was identified as -30 through day +30 . To study the impact of dividend announcement on firm value, Uddin (2003) used two measures

1) Daily market adjusted abnormal return (MAAR) and

2) Daily cumulative abnormal return (CAR)

The MAAR shows the change in the individual stocks value due to the dividend announcement. As the percentage change in market index (average market price) is deducted the remainder gives the unsystematic portion of the value change, which is specific to that particular stock resulting from its dividend announcement. Uddin (2003) used a 61 day window period, starting from -30 day to +30 day relative to the dividend announcement day (0-day). He also used a parametric test to determine the statistical significance of market adjusted average abnormal return of dividend paying stocks over the event window. The $t$ statistics were calculated cross sectionals by using the standard deviation of abnormal returns of the portfolio of 137 dividend paying stocks. The $t$ - statistic suggested in Brown and Warner (1980) was applied to test the significance of the cumulative abnormal returns.

Based on the 137 (DSE) listed companies declaring dividends during October 2001 and September 2002, Uddin found that investors do not benefit from a dividend announcement. Over the period starting from 30 days prior to the dividend announcement, investors lost up to 19.52 percent of their stock value. The CAR curve had a humps hope indicating the persistence of abnormal returns even though they were insignificant. The results therefore supported the Miller and Modigliani (1961) hypothesis of dividend announcement irrelevancy in determining stock value.

Scott et al (1996) examined the differential share price reaction to dividend increase and decrease announcements with respect to market phase (bull or Bear) They drew a sample from the Centre for research in securities prices (CRSP), new York stock exchange (NYSE) and American Exchange (AMEX) daily file. To qualify for inclusion in the sample, a firm was required to pay continuous, quarterly cash dividends over the period beginning two years prior to and ending two years following each individual phase period. This according to them helped eliminate the possibility of sampling bias resulting from companies announcing either an initial dividend, or resumption of a previously discontinued dividend. The sample therefore comprised of firms, which had historically provided a continuous long term reliable signal to investors through dividend announcements. They used the methodology of getting two market phases which were market phase (bull or Bear) They then identified strong market phases which were adjacent, and whose duration exceeded 12 months. All eligible firms from the CRSP file were tested from dividend changes during the selected market phase periods, with the first regular quarterly cash dividend announcement made within each phase being used as the initial reference point. In performing the task of parameter estimation for firms in the sample, to avoid sensitivity in the form of bias or instability with respect to market phase, the study used Klein and Rose field (1987) Single Index Market model (SIMM).On his part, Pettit (1972) investigated the relationship between dividend announcements security performance and capital market efficiency. He was interested in establishing whether the market makes use of announcement of dividends in assessing the value of a security Pettit selected his sample from: 
The announcement dates of all dividend change for a set of 625 New York Stock Exchange ( NYSE) companies for the period of January 1964) through June 1968 were collected from the Wall street journal index. The dividend data was taken from a tape constructed by the centre from research in securities prices at the University of Chicago updated at the university of Pennsylvania. Quarterly earnings information came from standard and poor quarterly COMPUSTAT tapes. In total there were approximately 1000 dividend changes announced by the 625 firms. The coefficients of the market model were estimated by regressing monthly firm investment relatives against the time relatives of Fisher's combination Investment Performance index. The number of months used in the regression varied between 24 and 111, and in all cases, the last observation used in regression was twelve months before the announcement

Daily price information was also collected from 135 announcement made in the $1967-1969$ period. The performance measures $\left(\delta_{u}\right)$ in the market model was estimated using the NYSE composite index after transforming $\alpha_{1}$ and $\beta_{1}$, originally calculated using Fisher's index, to take account of the differential slope coefficient for a firm between two indices. According to Pettit (1972) to develop a meaningful measure of performance, that adequately abstracts from the different risk characteristics of firm, the study made use of the ' market model' which argues that a security's return is the result of two factors: the first common to all securities, results in the tendency for stock prices to move together. The second factors unique to the individual firm affects only the return on the scurrilities to That firm. Mathematically, the market model posits a linear relationship between return on an individual security and the return on the market.

$$
R_{i t}=\alpha_{i}+\beta_{i} R_{m t}+\mu_{i t}
$$

$R_{i t}$ is the investment relative of the $i^{\text {th }}$ security in time period $t, R_{m t}$ is the investment relative of the market and $\mu_{i t}$ is a random error term incorporating the effect of factors that affect only the $i^{\text {th }}$ security. The coefficient $\beta_{i}$ measures the response of this security's return to factors that returns on all securities and since the effect cannot be diversified away, serves as a relative measure of the risk of holding the $i^{\text {th }}$ security. The random error term $\mu_{i t}$ I presumed to satisfy the conditions of a well-specified linear regression model. He continues that since the first two terms on the right of the equation (3) supply a conditional expected return for the $i^{\text {th }}$ security, the difference between the actual return in period $t$ and the conditional expected return in period $t$, given by:

$$
\delta_{i t}=R_{i t}-\left(\alpha_{i}+\beta_{i} R_{m t}\right)
$$

Serves as a measure of the risk adjusted abnormal performance of the security. In an efficient market, the value of $\delta_{i t}$ would be determined by information coming into the market that is unique to the $i^{\text {th }}$ firm. In the study, $\delta_{i t}$ was used to measure the effect of dividend announcements and the efficiency with which the effect was impounded into the price of the security. Care was taken by Pettit to avoid the effect of confounding effects through separation of the corporate actions and consideration of the days that the dividend announcements took place. Also, $\delta_{i t}$ was average across firms to effectively remove any potential bias in measuring risk-adjusted performance. The study found that dividend announcements are significant in determining firm value. Also, a spike in the shape of the CAR curve implying that Car did not persist over time was found for the stocks considered in the period under study. It was also found that most information implicitly in the announcement is reflected in the securities' prices as of the end of the announcement period (the largest change in most categories occurring in the announcement period).

Aharony and Swary (1980) sought to ascertain whether quarterly dividend changes provide information beyond that already provided by earnings numbers. A sample of 149 industrial firms was selected from those listed on the New York Stock Exchange (NYSE). Each firm had to meet the following criteria: first, its quarterly earnings per share and quarterly dividends per share including extra dividends, had to available on the quarterly industrial COMPUSTAT tapes of the Investor Management Sciences for the period .1963-1976. Second, its daily rates of return had to be available on the tapes constructed by the Center for Research in Securities' Prices (CRSP) at the University of Chicago for the period 1/1/63-13/31/76. Third, declaration dates of quarterly payment had to be available in the annual cumulative issued of Moody's Dividend Record. It was assumed that these dates were available through public media such as the Wall Street Journal. Finally, the announcement dates of quarterly earnings per share had to be available in the different annual issues of the Wall Street Journal index.

In addition, the daily closing standard and Poor's industrial common stock price index was obtained from the annual issues of standard and Poor's trade and securities statistics security price index record for the period 
1/1/63-12/31/76. Aharony et al. (1980) used the dividend expectation model and the market model to determine the effect of dividend announcements on stock price. To empirically examine the adjustment of common stock prices to quarterly dividend announcements, a measure of unexpected change in dividends was first derived. The expectation model used in the study was of the form that forecasted no change in dividends from one quarter to another, that is:

$\hat{D}_{j, q}=D_{j, q-1}$

Where $\hat{D}_{j, q}=$ expected divided per share for the $j^{t h}$ firm in the $q^{\text {th }}$ quarter

$\mathrm{D}_{\mathrm{j}-\mathrm{q}}=$ Actual divided per share announced by the $j^{\text {th }}$ firm in the $q^{\text {th }}$ quarter.

Accordingly, a dividend announcement was considered favourable if $\mathrm{D}_{\mathrm{j}-\mathrm{q}}>\hat{D}_{j, q}$, neutral if $D_{j-q}=\hat{D}_{j-q}$ and unfavourable if $\mathrm{D}_{\mathrm{j}-\mathrm{q}}>\hat{D}_{j, q}$.

Justification for the naïve expectation model in (5) was derived from the reluctance change dividend assertion, which states that managers do not change dividends payments unless they have reasons to expect a significant change in the future prospects of the firm. In order to isolate possible dividends effects from those of earnings, the study examined only those quarterly dividend and earnings announcements conveyed to the public on different dates within any quarter. The measurement of the abnormal performance was done by use of the market model. This study attempted to resolve the empirical issue as to whether or not, quarterly dividend announcements convey useful information beyond that provided by quarterly earnings numbers. Cumulative abnormal returns were found to be significant and the CAR was found to be spike shaped meaning that CARs rose sharply and then fell sharply in the event period. This implies non-persistence of CAR. Findings about the capital market reaction to be dividend announcements studies therefore strongly supported the hypothesis that changes in quarterly cash dividends provide useful information beyond that provided by corresponding quarterly earnings numbers. In addition the results also supported the semi-strong efficient capital market hypothesis, that on average, the stock prices adjust in an efficient manner to new quarterly dividend information. On his part, Woolridge (1982) sought to investigate whether or not, divided announcements contain information. In addition to other empirical studies done by Aharony and Swary (1980), Woolridge (1982) went a step further to provide more defensible measures of investors' expectation. The data used was that strictly available to the market at the time of the dividend announcement, and the influence of earnings on stock price was accounted for during the test period. His approach was considered superior by him to that of Aharony et al. (1980) because the latter used a naïve model where no dividend expectation models were initially tested by comparing dividend predictions in a hold out sample.

To determine the relationship between dividend announcement and stock prices, sampling was restricted to cases involving only announcement of changes in regular dividends published in the Wall Street Journal. The sample consisted of the dividend change announcements over the 1971 to 1977 period using a random sample of 200 firms, which met the following criteria: first , the announcement had to be made within a calendar fiscal year: second, the stock had to be listed on the New York Stock Exchange (NYSE); third, dividends and earnings announcement records had to be available on the annual industrial file of the COMPUSTAT tapes for 1959-1977; and finally, the firms had to be covered by value line and the standard and poor (S\&P) earnings forecaster over the 1970 to 1977 period. The study controlled for the influence of earnings and other extraneous information through the elimination from the sample whenever other significant announcements from the same firm were published in the Wall Street Journal during the period under consideration. For the 200 companies over the seven-year sample period, 835 dividend changes were announced according to the CRSP master file. 376 of these dividend change announcements (from 170 firms) met the sample screen that no other firm specific information was transmitted to the market during the period starting five days before and ending ten days after the dividend announcement day.

To measure the market's risk adjusted reaction to divided change announcements, the daily return, conditional on the daily market return was specified by employing the market model. In this study a stock's daily residual $\left(\mu_{i}\right)$ was obtained by subtracting the market's S \& P 500 daily return $\left(r_{m}\right)$ from the observed stock's return $\left(r_{i}\right)$. According to Woolridge (1982), the purpose here was to find whether or not, a stock's unexpected dividend and residual tends to be of the same sign around the information point. For each dividend observation, the behaviour of residuals was summarized by the sign and the level of an Abnormal Performance Index (API) measure equal to the sum of the stock's daily residuals in the event period, as follows: 


$$
A P I=\sum_{t=-5}^{+10} \hat{\mu}_{i t}=\sum_{t=-5}^{+10}\left(r_{i, t}-r_{m, t}\right)
$$

In the expression (6), day 0 is the publication date. The distribution of summed residuals for each information set was then used to make statistical inferences concerning the direction of the stock price movement. Another statistic, the Average Cumulative Average Residual (ACAR) was also calculated. ACAR, representing the mean cumulated residual value for each information set as of time $t$, was used to make judgments concerning the efficiency of the market in observing new information. For each information set, the Car as of day $\mathrm{T}$ was specified as:

$$
\operatorname{CAR}_{T, S}=\sum_{t=1}^{T} \sum_{s=1}^{S} \frac{r_{i, t, s}-r_{m, t}}{S}
$$

Where, $\mathrm{S}=$ the number of dividend observations in information set $\mathrm{s}$.

The statistical procedure employed was the Kruskal-Wallis one way analysis of variance test, which is sensitive to medians of two or more variables and has a chi-square distribution. In this test, the residuals in each pair-wise test are pooled and then ranked based on their ordinal size. If the residuals come from a distribution with the same median, the mean rank for each information set would be expected to be nearly equal. The chi-square statistic gives the likelihood that this is true. The study found that the mean market reaction to negative dividend information was almost twice $(-6.93 \%)$ that of the reaction to positive information 3.545. additionally negative dividend information was found to be more persistent than positive dividend information. According to Woolridge, the explanation may lie in the size of the unexpected dividends change. The study by Woolridge (1982) improved on part studies by using a tested ex-ante dividend expectation model, centering the analysis to daily as opposed to monthly returns and explicitly controlling for the influence of earnings. A hump shape of cumulative returns was found to hold, demonstrating the ACAR persisted over time in the period under consideration.

Kwan (1981) sought to solve the controversy formed in finance literature regarding the empirical evidence of the informational content of dividends by evaluating and extending Watts' (1973) methodology. He considered three methodological issues: First, the standard Lintner (1956) and Fama-Babiak (1968) annual dividend models (which were used to identify the firm's potential dividend information in Watts' study) were refined to incorporate quarterly earnings and dividend data. Second, the potential problem of misclassification of information due to the inherent noise of empirical models which may have contributed to Watts' results, was treated by a filtering process based on the concept of prediction intervals. Third, the study isolated dividend announcement information from the firm's other publicly available information. According to Kwan (1981) the Fama-Babiak model are unsuitable for the purpose of identifying information from quarterly dividend announcements given the fact that they only explain annual dividend changes, regardless of when the information becomes publicly available during the firm's fiscal year. A test based on annual models could only treat the information as if it were associated solely with the dividend declared during that particular quarter. To obtain a more appropriate identification of the information associated with a quarterly dividend announcement, Kwan (1981) relaxed the definition of the fiscal year by treating any four consecutive quarters as one year in the two models.

Lintner equation or,

$$
\Delta D_{q, t} \equiv D_{q, t}-D_{q, t-1}=\alpha_{0}+\alpha_{1} D_{q, t-1}+\alpha_{2} E_{q, t-1}+Z_{q, t}
$$

Fama-Babiak equation, with $\mathrm{q}=1,2,3,4$.

$$
\Delta D_{q, t} \equiv D_{q, t}-D_{q, t-1}=\alpha_{1}^{\prime} D_{q, t-1}+\alpha_{2}^{\prime} E_{q, t}+\alpha_{3}^{\prime} E_{q, t-1}+Z_{q, t}^{\prime}
$$

Here, the moving annual earnings $E_{q . t}$ are the sum of the firm's four consecutive quarterly earnings ending at quarter q of year t. the moving annual dividend $D_{q-t}$ is the sum of the firm's four consecutive quarterly announced dividends (including regular and extra dividends). Contemporaneous with $E_{q . t}$ in this models $Z_{q, t}$ and $Z_{q, t}^{\prime}$, are the error terms. To take care of noise regression Kwan (1981) treated the noise problem by constructing a filter using prediction intervals. This was done by letting the filter be a 95 percent prediction for $D_{q-t}$ according to a particular model. If the actual $D_{q-t}$ falls within this interval there is a 95 percent probability that either the dividend announcement conveys no information or the model is unable to identify the potential signal from the announcement because of the noise problem. If however, the announced $D_{q-t}$ falls outside this interval, there is only a 2.5 percent probability that the announcement is incorrectly classified. Therefore the prediction interval can serve as a filter to remove potentially misclassified cases for the two information groups 
categorized according to the sign of $D_{q, t}-\hat{D}_{q, t}$. On the assumption that all relevant corporate news was reported daily in the Wall Street Journal (WSL) and summarized in the Wall Street Journal Index, Kwan (1981) identifies those dividend announcements, which were separable from other sources of information.

Firms included in the sample were restricted to those reported in Moody's Handbook of common stocks and listed on the NYSE. The announcements collected from the WSJI included regular dividend changes and extra dividends declared during the period 1973-1977. for the purpose of estimating the parameters in (1) and (2), each firm's quarterly earnings and dividend per share data were collected from the value line data base and Moody's dividend records for a period of 11 years up to the quarter under consideration. According to the sample selection criteria of the study, 183 announcements of regular dividend changes and extra dividends were collected. In the sample, there were only 20 cases of regular decreases including dividend omissions. Empirical models (1) and (2) with the dividend variable measured by the moving annual divided were initially used to identify potential information from all these announcements. Upon replacing the dividend variable in these models by annualized quarterly dividend, the number of eligible cases for the analysis was reduced from 183 to 147.In conclusion, for all filtered and unfiltered information groups classified according to empirical models whose dividend variables was the annualized quarterly dividend, statistically non zero average residuals (as the $0.010 \mathrm{r} 0.005$ ) of correct signs were observed around the dividend announcement day. This evidence supported the position of dividend non-triviality. However, the shocks due to dividend announcements were found to be temporary as observed from the spike shape of the cumulative average returns curve. While there was a strong past and concurrent link between market value and dividend announcements, the information content of dividends was found to be minimal. However, according to their findings, announcements involving cuts relatively signal an increase in future firm value. They also found evidence of dividend-increase announcing firms being less likely to have subsequent earnings decreases than firms that do not make announcements changing their dividends despite similar earnings growth. In this context, according to them, dividend announcements do contain information about the present and the future: the current increase in earnings in permanent signaling a spike in the ACAR curve.

\section{Research Methodology}

\subsection{Research design}

The researcher design adopted in this study was descriptive in the sense that descriptive characteristics of the dividends announced by four firms selected and their respective stock prices, returns and cumulative abnormal returns collaborated with graphical presentation would be provided. Also, a regression technique would be based on the event study analysis. This would give both the quantitative and qualitative results that are not only robust but also conclusive. STATA package collaborated with SPSS and Excel packages were used in the analysis.

\subsection{Population}

The population of interest comprises of the 52 listed companies and the NSE. This population is idea in that it mirrors the true picture of active companies in the economy. The other companies that are not listed are small firms or they do not meet the listing requirements of the NSE and the rules of the CMA. This population provided the universe from which a sample was drawn, and therefore secondary data obtained.

\subsection{Sampling design}

The purposive sample of the four companies was drawn from the target population each from firms that made final dividend announcements. The companies were selected based on consistency in final dividend announcements. This enabled the study objectives to be achieved while addressing the main issues under investigation.

\subsection{Data collection}

The data used in the analysis was purely secondary data. The data was collected from the NSE, cleaned and sorted and collated for analysis. The data collected include the number of firms listed on NSE, the four selected firms based on consistent dividend announcements and the stock prices of those firms and the market index.

\subsection{Data analysis and estimation procedures}

In financial economics literature, an event is defined as some change, development or announcement that may produce a relatively large change in the price of an asset listed on a stock exchange over some specified time period. The event study methodology that was used in the data analysis follows six steps in establishing the significance of the relationship between an event (dividend announcements) and changes in stock prices or return is as follows:

This is the first step in event study methodology. It involves defining the event that should be analyzed and reasons why such an event is chosen. Examples of events are such as earnings, corporate take-over, changes of the business 
regulatory environment, stock splits, stock issuance, hiring and firing of high level officers and change in the normal return which is the expected return without conditioning on the event taking place for firm $i$ and even date $r$ the normal return is:

Where:

$$
E\left(R_{i r} / \Omega_{t-1}\right)
$$

$\mathrm{E}=$ The expectation for the time period $\mathrm{r}$,

$\mathrm{R}_{i r}=$ The actual return and

$\Omega_{t-1}=$ The conditioning information for the normal return model.

The two common choices for the modeling the normal returns are; the constant mean return model which assumes that $\Omega_{t-1}$ is a constant through time and the market model, which assumes a stable linear relationship between the market return and the security return. The market model is an improvement over the constant mean return model because it removes the portion of the return that is related to the variation of the market return. This leads to variance of the abnormal return being reduced, meaning an increased ability to detect event effects. The estimation window which is represented by the period prior to the event window is then identified. The event period is not included in the estimation period to prevent the event from influencing the normal performance model parameter estimates. Equation 1 above is then estimated by the market model of the form;

$$
R_{i r}=\hat{\propto}_{i}+\hat{\beta}_{i} R_{m r}+\hat{\varepsilon}_{i r}
$$

$E\left(\varepsilon_{i r}\right)=0$

$\operatorname{Var}\left(\varepsilon_{i r}\right)=\hat{\sigma}_{\varepsilon i}^{2}$

Where:

$R_{i r}=$ period $r$ returns on security 1 ,

$R_{m r}=$ Period $\mathrm{r}$ returns on market portfolio and

$\varepsilon_{i r}=$ Zero mean disturbance term

$\hat{\sigma}_{i}, \hat{\beta}_{i}$ and $\hat{\sigma}^{2}{ }_{\varepsilon i}=$ are the estimated parameters of the market model.

The potential abnormal returns are then calculated using the model

$$
A R_{I R}=R_{i r}-E\left(R_{i r}\right)
$$

The above model is then estimated by the equation;

$$
A R_{i r}=\hat{\varepsilon}_{i r}^{*}=\hat{\alpha}_{i}-\hat{\beta}_{i} R_{m r}^{*}
$$

$\hat{\varepsilon}_{i r}^{*}-N\left(O, V_{i r}\right)$

Where:

$A R_{i r} \quad=$ The "hats" denote the estimated values of parameters from the estimated window.

$R_{i r}^{*}=$ The event window stock returns generated from stock prices of the selected firms.

$R_{m r}^{*}=$ The event window market returns generated from the market index.

$\hat{\varepsilon}_{i r}^{*}=$ The residual generated from equation 4 .

After the above process, the abnormal returns are then cumulated over time and across firms to get "cumulative abnormal returns" in the event window.

$$
\begin{aligned}
& C_{i}=\sum_{r=T_{1}+1}^{T_{2}} \hat{\varepsilon}_{i r} \\
& A C A R=\bar{\varepsilon}^{*}=\frac{1}{N} \sum_{i=1}^{N} \hat{\varepsilon}_{i r}^{*}
\end{aligned}
$$


$\operatorname{Var}(A C A R)=\sigma_{A C A R}^{2}=N^{2} \sum_{i=1}^{N} \hat{\sigma}_{c a r, i}^{2}$

$A C A R \approx N\left(0, \bar{\sigma}^{2}\right), N=$ Normal distribution

Where:

$C A R_{i}=$ The cumulative Abnormal Return for firm $i$.

$A C A R_{i}=$ The average cumulative Abnormal Return for firm $i$.

$\mathrm{N}=$ the number of days in the event window.

\section{Diagnostic Tests}

Parametric tests, which assume normally in the distribution of average cumulative abnormal returns or non-parametric tests, which assume that the average cumulative abnormal returns are not normally distributed, are used to determine the significance of abnormal returns. Under the null hypothesis that the abnormal returns are insignificant, the distribution of $A C A R / \sigma_{A C A R}$ is asymptotically normal with zero mean and unit variance. Mathematically;

$$
S A R_{i r}=\frac{A R_{i r}}{S\left(A R_{i}\right)}
$$

Where:

$S A R_{i r}=$ Standard abnormal returns of firm $i$ at time $r$

$A R_{i r}=$ Abnormal returns of firm $i$ at time $r$

$S=$ Standard error

For the parametric test, the test statistic of the hypothesis that the average standardized residuals across firms is equal to zero is computed as:

$$
Z \frac{S_{i r}}{S\left(\operatorname{SAR}_{i r}\right)}=N^{-1} \frac{\sum_{i=1}^{N} S A R_{i r}}{S\left(S_{i r}\right)}
$$

Considering independence across firms and that abnormal returns are independently distributed and that:

$$
S\left(S_{i r}\right)=\frac{1}{\sqrt{N}}
$$

The standardized abnormal return would follow at distribution with N-1 degrees of freedom. Years 1999-2003. Third, it did not announce earnings for at least 7 trading days prior to and after the dividend announcement day. Fourth, it consistently announced final dividends for each of the five years under study. Finally, it traded for at least 100 days or more in the 6-month estimation window.

\section{Measurement of normal returns}

The normal returns arising from the assumption that divided announcements have no impact on stock prices was measured using the market model. Normal returns were generated on the premise that there were no unanticipated dividend announcements. Additionally, abnormal returns based on the difference between actual and expected returns assuming the announcements that are unanticipated was also generated. The market model was used because of it being an improvement on the constant mean return and therefore reducing the variance of the abnormal return leading to increased ability to detect event effects. The market model is also preferred because it overcomes the shortcomings of the capital asset pricing model and the Arbitrage pricing theory like testability of a model's validity. The market model for security $\mathrm{s}$ and observation $\mathrm{t}$ in event time was calculated as;

$$
R_{s t}=\beta_{0}+\beta_{1} R_{m t}+\varepsilon_{s t}
$$

The above model was estimated from the estimation window observations using Ordinary Least Squares (OLS).

Where: $\mathrm{R}_{\mathrm{st}}=$ the rate of return of the common stock of firm $s$ on day $t$. 
$\mathrm{R}_{\mathrm{st}}=$ The In Price $\mathrm{s}, \mathrm{t}-$ In Price $_{\mathrm{s}, \mathrm{t}-1}$.

$\mathrm{R}_{\mathrm{mt}}=$ The NSE 20 share index return at time $t$.

$\mathrm{R}_{\mathrm{mt}}=$ In S1t- In $\mathrm{S} 1_{\mathrm{t}-1}$.

In= Natural logarithm

$\mathrm{S} 1=$ stock market index

$\beta_{s}=$ Coefficients estimated using OLS from a regression of daily security returns on daily market index for the estimation window $\left(T_{0}+1\right.$ to $\left.T_{1}\right)$ preceding the dividend announcement.

$\varepsilon_{s t}=$ The residential for stock s at time t with $E\left(\varepsilon_{s, t}\right)=0$. From equation (10) above, the estimated coefficients $\hat{\beta}_{0}$ and $\hat{\beta}_{1}$ will be estimated.

\section{Definition of the estimation window and the framework for abnormal returns.}

The period before the event ( 6 months) would be the estimation window. The event window and the estimation window would be separated to avoid overlapping and in the process biasing the results. The abnormal return will be calculated as:

$$
A R_{s t}=\hat{\varepsilon}_{s t}^{*}=R_{s t}^{*}-\hat{\beta}_{0}-\hat{\beta}_{i} R_{m t}^{*}
$$

Where: $\hat{\varepsilon}_{s t}=$ the residual generated from equation (11)

$R_{s t}^{*}=$ The event window returns generated from the stock prices of the selected sample of firms.

$R_{m t}^{*}=$ The event window market returns generated from the 20 share NSE index.

Under the assumption of normal distribution, the abnormal returns are assumed to be jointly normally distributed and following a student $t$ distribution. Under the null hypothesis, Ho, that dividend announcement has no impact on the mean of variance of returns; the normal distribution assumption was used to draw inferences about the behaviour of abnormal returns.

$$
\hat{\varepsilon}_{s t}^{*} \approx N\left(0, V_{s t}\right)
$$

Where $\mathrm{V}$ is the variance

Defining the ACAR as the cumulative average abnormal return, for the event window;

$$
\begin{aligned}
& A C A R=\bar{\varepsilon}^{*}=\frac{1}{N} \sum_{i=1}^{N} \hat{\varepsilon}_{s t}^{*} \\
& \operatorname{Var}\left(\bar{\varepsilon}_{s}^{*}\right)=V=\frac{1}{N} \sum_{i=1}^{N} V_{s t}
\end{aligned}
$$

Where: $\mathrm{N}=$ Number of observations in the event window

$$
\sum=\text { Cumulation. }
$$

Given that the event window of the $\mathrm{N}$ securities does not overlap with the estimation window, the covariance terms were set to Zero so that inferences can be made about the cumulative abnormal returns using:-ACAR using the event window $\approx N\left(0, \sigma^{-2}\right)$

\section{Diagnostic Tests}

Parameter tests, which rely on the assumption that individual firm's abnormal returns are normally distributed, were used. The computed $t$ using standardized abnormal returns would be calculated and compared to the critical tvalue from the tables at $\mathrm{N}-1$ degrees of freedom to make statistical inferences.

The standardized residuals given by the equation below were generated thus:

$$
A R_{s t}=\frac{A R_{s t}}{S\left(A R_{s}\right)}
$$


Where: $A R_{s t}=$ Abnormal returns of firm $s$ at time $t$.

$\mathrm{S}=$ Standard error of the abnormal return of firms.

The test statistic of the hypothesis that the average standardized residuals across firms is equal to zero would be computed as:

$$
Z=\frac{A R_{s t}^{1}}{S\left(A R_{s t}^{1}\right)}=\frac{1 / N \sum_{i=1} A R_{s t}^{1}}{S\left(A \bar{R}_{s t}^{1}\right)}
$$

Considering independence across firms, and that abnormal return are independently distributed, and that:

$$
S\left(A R \quad \begin{array}{l}
1 \\
s t
\end{array}\right)=\frac{1}{\sqrt{N}}
$$

The abnormal returns are assumed to follow a student-t distribution. The generated standardized abnormal returns would be compared with the critical value of the t-statistic from the tables to determine the significance of the average cumulative abnormal returns.

\section{Data Analysis and Presentation of Results}

\subsection{Descriptive statistics}

The selected companies that made up the study sample went through a rigorous filtering process outlined in the sample selection criteria. Four firms namely: Barclays Bank of Kenya, NIC Bank and Standard Chartered Bank (all from the financial sector) and East African Breweries Limited (from industrial and allied sector) met the criteria. There are no other firms from the remaining sectors that met the selection criteria. The selected sample of companies was among the twelve companies that consistently announced final dividends in the period 1999-2003. In addition, these four firms had at least a hundred daily trading observations in the same period. Insert table 1 in the space below

From the sample selected, it was noted that the highest amount of dividend paid was by East African Breweries Limited (EABL) in 2003, which announced a final dividend of Sh. 12.00. In contrast, National Industrial Credit Bank (NIC) recorded the lowest dividend payout (Sh. 1.00) in 1999 and 2002. Additionally, on average, Barclays Bank of Kenya (BBK) made the highest dividend announcement, followed by EABL, Standard Chartered Bank (SCB) and NIC in that order. In terms of individual company dividend announcements, BBK registered its highest dividend payout in 2002 (Sh. 11.25), and the lowest value in 2003 (Sh. 6.00). EABL had its lowest dividend value in 1999 (Sh. 5.00) and its highest dividend value in 2003 (Sh. 12.00). NIC Bank registered its highest dividend payout in 2003 (Sh. 1.40) and its lowest dividend value in 1999 and 2002 (Sh. 1.00). In percentage terms, SCB registered the highest percentage change in dividend announcement in a single year $71.43 \%$ in 1999 .

In contrast, BBK registered in the highest negative percentage change (-46.67\%) in 2003. Column 7 of Panel 3 in table 4.1 above shows the average percentage increase (decrease) of dividend values in the period under study. On average SCB registered the highest positive change. Additionally, as shown in the column, it is only BBK that registered an averaged negative dividend value. From the dates of final dividend announcements in the period under study, it can be noted that the financial sector, represented by BBK, SCB, and NIC bank made final dividend announcements at about the same time (February or March), whereas the industrial and allied sector represented by EABL made its final dividend announcement in September.

This study therefore, made a contribution towards resolving the empirical issue as to whether final dividend announcements convey useful information to capital market participants with specific reference to a selected sample of firms listed on the Nairobi Stock Exchange. Such an attempt was crucial in establishing the validity of the "informational content of dividends" hypothesis. To achieve our objectives, our study examined the association between unexpected final dividends and changes in firm value as measured by variations in stock price of the affected firms using the event study methodology. To test the significance of the average cumulative abnormal returns (ACAR), a parametric test assuming a student distribution was used. Using a sample drawn from the period 1999-2003, the results showed a significant relationship between dividend announcements and firm value.

Also, the platykurtic (flatter than the normal distribution curve) shape of the ACAR curve, meaning a hump shape, lends credence to the argument that abnormal returns persisted for some time after the announcement of dividends, 
although the curve has some spikes as shown in the Average Cumulative Abnormal Return curve. This is consistent with Woolridge (1982) finding that dividend announcements contain information that affects stock prices. The average cumulative abnormal returns observation reduced to 40 because of lagging and thereby losing one degree of freedom. The test of the null hypothesis that average cumulative returns were not normally distributed was rejected and the joint probability that they were normally distributed was found to be 0.9775 (1-0.0225). Jarque-Bera - A test for normality of a distribution. The closer its probability is to Zero the more the probability of approximating a normal distribution. Pr-Probability, Adjusted Chi-square, as shown in table 2 the Average Cumulative Abnormal Return (ACAR) data was also found to be skewed to the right with a value of -0.12973 and the probability of kurtosis approximating the normal distribution was found to be 0.004 . Also, the Kurtosis value was 1.796103 .

\section{Conclusion}

In conclusion, the results in the study show a significant relationship between unexpected dividend announcements and abnormal stock return; and therefore support the hypotheses that: First, dividends announcements have information content. This means the null hypothesis that dividend announcements have no information content is rejected with 95 percent confidence level. Second, the null hypothesis that dividend announcements have no influence on firm value is also rejected at the same level of confidence. This means that the information contained in dividend announcements has influence on a firm's future value. Finally, the NSE is not semi-strong form efficient as some investors can earn abnormal returns by having unequal access to public information.

\subsection{Areas for further research}

There is need for a thorough research on the effect of dividend announcement on firm value to be conducted on a sector-by-sector basis. The firms need to be drawn from the five sectors (agriculture, commercial \& services, finance \& investment and industrial \& allied sectors from the main investment market segment and alternative sector from the alternative investment market segment). This sample from a population of all the listed companies on the exchange will provide not only a well representative sample, a stable period of analysis but also a clear picture on the relationship between dividend announcements on firm value on a sector by sector basis, looking at the various market phases. The firms selected, one from each sector, will be based on the availability of the information on the variables to be examined, which is dividend announcements and stock price. This will help uncover the effect of dividend announcement on firm value on a sector by sector basis and what this implies on the efficiency of the NSE.

\section{References}

Aharony, J. and Swary I. (1980). Quarterly dividend and earning announcements and stockholders' returns: An empirical analysis. Journal of finance, Vol. 35:1-2. http://dx.doi.org/10.2307/2327176

Besslers, W. T. (2000). Asymmetric information, dividend reductions, and contagion effect in bank stock returns. Journal of Banking and Finance, Vol. 24: 1831-1848. http://dx.doi.org/10.1016/S0378-4266(99)00097-7

Bessler, W. \& Nohel, T. (1996). The stock-market reaction to dividend cuts and omissions by commercial banks. Journal of Banking and Finance, Vol. 24: 1485-1508. http://dx.doi.org/10.1016/S0378-4266(96)00004-0

Bhattacharya, S. (1979). Imperfect information, dividend policy and the bird in hand fallacy. Bell Journal of Economics, Vol. 10 (Spring 1979): 259-270. http://dx.doi.org/10.2307/3003330

Brennan, M. J. (1970). Taxes, market valuation and corporate financial policy. National Tax Journal, Vol. 26: 1115-1121.

Brown, S. J. \& Warner, J.B. (1980). Measuring securities price performance. Journal of Financial Economics, Vol. 8: 205-258. http://dx.doi.org/10.1016/0304-405X(80)90002-1

Dolley J. (1993). Characteristics and procedure of common stock split-ups. Havard Business School Review, 316-326.

Fama, E.F. (1970). Efficient capital markets: A review of theory and empirical work. Journal of Finance, Vol. 25(2): 383-423. http://dx.doi.org/10.2307/2325486

Fama, E.F. (1991). Efficient capital markets II. Journal of Finance, Vol. 46(5): 1575-1615. http://dx.doi.org/10.2307/2328565

Fama, E.F. and H. Bakiak. (1968). Dividend Policy: An empirical analysis. Journal of American Statistical Association, Vol. 63: 1132-1161. http://dx.doi.org/10.2307/2285874 
Fama, R., Fisher, L., Jensen, M. \& Roll R. (1969). The adjustment of stock prices to new information. International Economic Review, Vol. 10: 1-21. http://dx.doi.org/10.2307/2525569

Gordon, M.J. (1959). Dividends, earnings, and stock prices. The Review of Economics and Statistics, Vol. 41:99-105. http://dx.doi.org/10.2307/1927792

Jensen G. \& Johnson, J. (1995). The dynamics of dividend reductions. Financial Management, Vol. 24(4). http://dx.doi.org/10.2307/3665949

Jensen M. (1986). Agency costs of free cash flow, corporate finance, and takeovers. American Economic Review, Vol. 76: 323-329.

Kalay, A \& Lowenstein, U. (1980). The information content of the timing of dividend announcements. Journal of Financial Economics, Vol. 16: 373-38. http://dx.doi.org/10.1016/0304-405X(86)90035-8

Kim O. \& Verrecchia R.E. (1991a). Trading volume and price reactions to public announcements. Journal of Accounting and Research, Vol. 29: 302-321. http://dx.doi.org/10.2307/2491051

Kim O. \& Verrechia R.E. (1991b). Market reaction to anticipated announcements. Journal of Financial Economics, Vol. 30: 273-309. http://dx.doi.org/10.1016/0304-405X(91)90033-G

Klein, A. \& Rosenfeld, J. (1987). The influence of market conditions on the event study residuals. Journal of Quantitative and Financial Analysis, 345-351.

Kwan C. (1981). Efficiency market tests of the information content of dividend announcements: Critique and extension. Journal of Financial and Quantitative Analysis, Vol. $16 \quad$ (June): $193-206$. http://dx.doi.org/10.2307/2330646

Lintner, J. (1956). The distribution of incomes of corporations among dividend, retained earnings and taxes. American Economic Review, Vol. 46: 7-13.

Litzenberger, R.H. \& Ramaswamy, K. (1979). The effects of personal taxes and dividends on capital asset prices. Journal of Financial Economics, Vol. 7: 163-195. http://dx.doi.org/10.1016/0304-405X(79)90012-6

Mac Kinlay, C.A. (1997). Event studies in economics and finance. Journal of Economic Literature, Vol. 35(35): 13-39.

Mc Williams, A. \& Siegel, D. (1997). Event studies in management research: Theoretical and empirical issues. Academy of Management Journal, Vol. 40(3): 626-957. http://dx.doi.org/10.2307/257056

Michaely, R., Thaler, R.H. \& Womack, K.L. (1995). Price reactions to dividend initiations and omissions: Overreaction of drift? Journal of Finance, Vol. 50: 573-608. http://dx.doi.org/10.2307/2329420

Miller, M. \& Modigliani, f. (1961). Dividend policy, growth, and the valuation of shares. Journal of Business, Vol. 4:411-433. http://dx.doi.org/10.1086/294442

NSE Handbook. (2004-2005). A Publication of the Nairobi Stock Exchange, $4^{\text {th }}$ Edition. Nairobi.

Peterson, P.P. (1989). Events Studies: A review of issues and methodology. Quarterly Journal of Business and Economics, 36-66.

Pettit R. R. (1972). Dividend announcements, security performance, and capital market efficiency. Journal of Finance, Vol. 27 (August 1972): 993-1007. http://dx.doi.org/10.2307/2978844

Pye, G. (1972). Preferential tax treatment of capital gains, optimal dividend policy and capital budgeting. Quarterly Journal of Economics, May.

Scott D. B. \& Keith H. J. (1996). An analysis of shareholder reaction to dividend announcements in bull and bear markets. Journal of Financial and Strategic Decisions, Vol. 9 (Fall): 15-25.

Serra P.A. (2002). Event study tests-a brief survey. Working Paper Da FEP No. 117, Fall, 2-12.

Uddin H. (2003). Effect of dividend announcement on shareholders' value: Evidence from Dhaka Stock Exchange. Finance and Banking, pp 1-16.

Watts, R. (1973). The information content of dividends. Journal of Business, Vol. 46 (April): $191-211$. http://dx.doi.org/10.1086/295525

Williams, J.T. (1992). Signaling with dividends, in Newman, P., Murray, M. and Eatwell, J. (Eds.), The Palgrave Dictionary of Money and Finance, Vol. 1. London, 458-461.

Woolridge, J.R. (1982). The information content of dividend changes. Journal of Financial Research, Fall, $237-247$. 
Table 1. Values of Final Dividends, Announcement Dates and Percentage Dividend Changes for the Selected Sample (1999-2003)

\begin{tabular}{|c|c|c|c|c|c|c|}
\hline \multicolumn{7}{|c|}{ Panel 1: The Value of Final Dividends for Selected Sample (1999-2003) } \\
\hline \multirow{2}{*}{\multicolumn{2}{|c|}{ Company }} & \multirow{2}{*}{$\begin{array}{l}1999 \\
\text { Sh. }\end{array}$} & 2000 & \multicolumn{2}{|l|}{2001} & 2003 \\
\hline & & & Sh. & Sh. & Sh. & Sh. \\
\hline \multicolumn{2}{|l|}{ BBK } & 8 & 7.5 & 7.5 & 11.25 & 6 \\
\hline \multicolumn{2}{|l|}{ EABL } & 5 & 5.5 & 6.75 & 9 & 12 \\
\hline \multicolumn{2}{|l|}{ NIC Bank } & 1 & 1.05 & 1.05 & 1 & 1.4 \\
\hline \multicolumn{2}{|l|}{ SCB } & 3 & 5 & 6.6 & 4.25 & 3.85 \\
\hline \multicolumn{7}{|c|}{ Panel 2: Dates of Final Dividends (1999 -2003) } \\
\hline \multicolumn{2}{|c|}{ Company } & 1999 & 2000 & 2001 & 2002 & 2003 \\
\hline \multicolumn{2}{|l|}{$\mathrm{BBK}$} & $16 / 2 / 99$ & $15 / 2 / 00$ & $13 / 2 / 01$ & $14 / 2 / 02$ & $20 / 2 / 03$ \\
\hline \multicolumn{2}{|l|}{ EABL } & $16 / 9 / 99$ & $4 / 9 / 00$ & $3 / 9 / 01$ & $2 / 9 / 02$ & $1 / 9 / 03$ \\
\hline NIC BANK & & 2/3/99 & $6 / 3 / 00$ & $1 / 3 / 01$ & $27 / 2 / 02$ & $25 / 2 / 03$ \\
\hline $\mathrm{SCB}$ & & $1 / 3 / 99$ & $23 / 2 / 00$ & $22 / 2 / 01$ & $21 / 2 / 02$ & $20 / 2 / 03$ \\
\hline Panel 3: Perc & Change & of Final Di & ds for Sele & d Sample (19 & 003) & \\
\hline Company & 1999 & 2000 & 2001 & 2002 & 2003 & Average \\
\hline & $\%$ & $\%$ & $\%$ & $\%$ & $\%$ & $\%$ \\
\hline $\mathrm{BBK}$ & -11.11 & -6.25 & 0 & 50 & -46.67 & -3.5075 \\
\hline EABL & 25 & 10 & 22.73 & 33.33 & 33.33 & 31.0975 \\
\hline NIC Bank & - & 5 & 0 & -4.76 & 40 & 10.06 \\
\hline SCB & 71.43 & 66.67 & 32 & 35.6 & -9.41 & 49.0725 \\
\hline
\end{tabular}

Source: NSE Handbook (Various Issues)

\section{Legend:}

Sh. - Kenya Shillings

NIC - National Industrial Credit Bank.

SCB- Standard Chartered Bank

Table 2. The Distribution of the ACAR for the Selected Sample (1999-2003)

\begin{tabular}{|l|l|}
\hline Statistic & Average Cumulative Abnormal Return \\
\hline Mean & 0.040536 \\
\hline Median & 0.034918 \\
\hline Maximum & 0.075634 \\
\hline Minimum & -0.006168 \\
\hline Standard Deviation & 0.025190 \\
\hline Skewness & -0129733 \\
\hline Kurtosis & 1.796103 \\
\hline Jargue-Bera & 2.527816 \\
\hline Probability & 0.282548 \\
\hline Observations & 40 \\
\hline Pr (Skewness) & 0.704 \\
\hline Pr (Kurtosis) & 0.004 \\
\hline Adj chi2 (2) & 7.58 \\
\hline Pr>chi2 & 0.0025 \\
\hline
\end{tabular}

BBK-Barclays Bank of Kenya. EABL- East African Breweries Limited. 


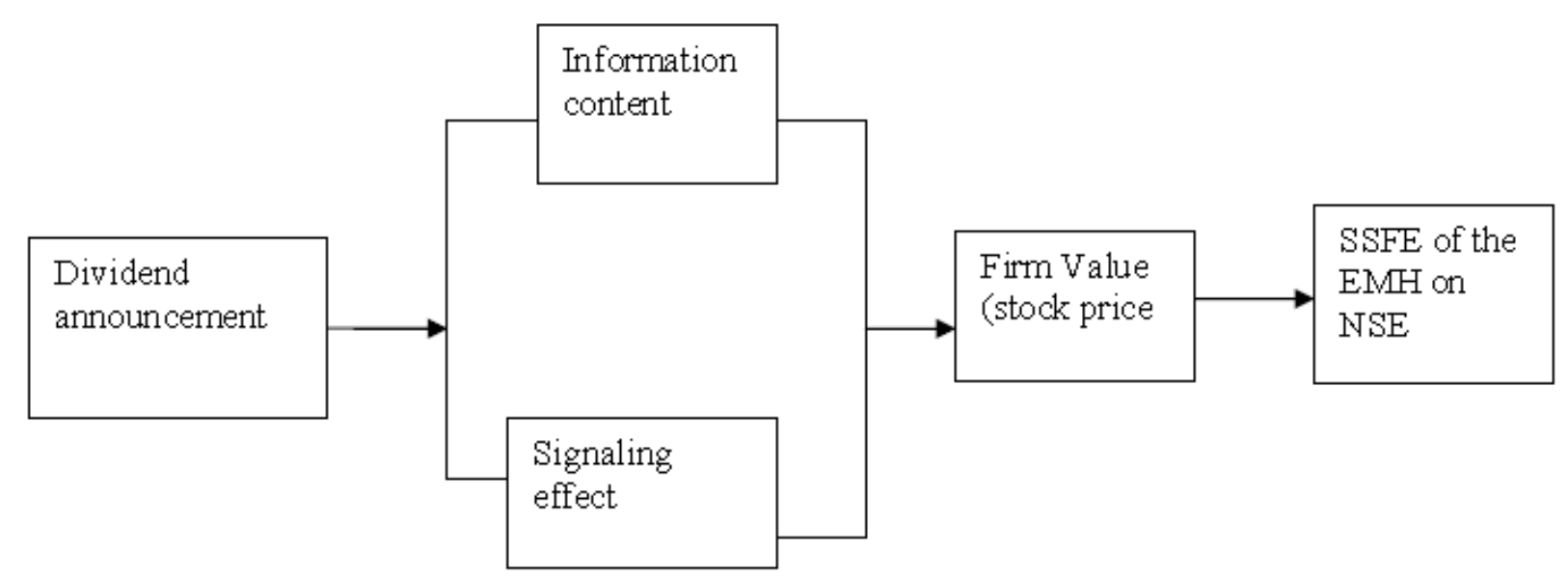

Figure 1. 